\title{
Perceptions of Satisfaction That Motivate Tourists to Visit Religious Tourism Destinations During COVID-19 Pandemic
}

\author{
Kukuh Lukiyanto $^{1 *}$, EtsaAstridya Setiyati ${ }^{1}$, Choirul Huda ${ }^{2}$, Albert Verasius Dian \\ $\mathrm{Sano}^{2}$ \\ ${ }^{\text {I} E n t r e p r e n e u r s h i p ~ D e p a r t m e n t, ~ B I N U S ~ B u s i n e s s ~ S c h o o l ~ U n d e r g r a d u a t e ~ P r o g r a m, ~ B i n a ~ N u s a n t a r a ~ U n i v e r s i t y, ~}$ \\ Jakarta Indonesia \\ ${ }^{2}$ Computer Science Department, School of Computer Science, Bina Nusantara University, Jakarta Indonesia \\ *Corresponding author email: kukuh.lukiyanto@binus.ac.id
}

\begin{abstract}
Religious tourists have a unique character and are different from tourists in general. The desire to visit religious tourism destinations is more based on obligation instead of interest. Therefore, during the COVID-19 pandemic, many tourists are still visiting religious tourism spots.Purpose: This study aims to reveal the factors that are considered by tourists visiting religious tourism destinations during the COVID-19 period.Methods: Using qualitative methods with a descriptive approach, this study maps information from informants to be processed into a conclusion. Informants are those who continue to visit religious tourist destinations in Malang Raya-Indonesia, during the COVID-19 pandemic.Results: The results of the study conclude that there are two main factors that measure the perception of satisfaction and encourage tourists to visit religious tourism destinations during COVID-19, namely: the belief in getting answers to prayed prayers and COVID-19 prevention protocols implemented by managers of religious tourism destinations.Recency: This research fills a gap where there have been changes in people's behavior and lifestyle due to COVID-19. All activities have changed according to the conditions of the COVID-19 pandemic, including in the field of religious tourism.Benefits: The results of this study can be used for tourist destination managers to determine marketing strategies in the COVID-19 pandemic era, especially in tourism promotion and development of their digital marketing content.
\end{abstract}

Keywords: Motivate Tourists, Religious Tourism, Destinations, COVID-19 Pandemic

\section{INTRODUCTION}

Religious tourism, well-known as pilgrimage [1],is motivated by spiritual reasons [2]. During COVID19 pandemic, religious tourism is still in demand by tourists, including those in Malang Raya. One of the most well-known religious tourism destinations in Malang Raya is PesareanGunungKawi, a site in the form of a temple building adjacent to the heritage mosque of Padepokan RM Imam Soedjono[3]

Before the COVID-19 pandemic, tourist visits increased and reached 160,000 number of tourist visits in 2018. The increasing number of visits triggered by the tourist satisfaction factor, those who were satisfied are more likely to return and influence other people to visit. The satisfaction is generally not based on attractive objects, the availability of facilities, services, and attractions [4], but due to the 'achievement of their spiritual goals'. This is what distinguishes it from previous studies on tourist destinations. This perception of satisfaction and the achievement of spiritual goals needs to be explored deeply to discover the driving factor for tourists to become loyal toward religious tourism destinations.

The loyalty of religious tourists to a tourist destination cannot be defeated by anything, including COVID-19. This is proven by many tourists who come to religious tourism destinations. They are willing to queue for hours or even days to be able to enter and carry out pilgrimages, due to restrictions on visitors (in an effort to prevent the transmission of COVID-19). This is an opportunity to dig deeper into how the perception of satisfaction is in their minds.

The results of this study can be used as a basis for developing a marketing strategy in order to develop the potential of existing religious tourism. In addition, it can be used as a reference for developing other religious tourism destinations to bring in tourists during the COVID-19 pandemic. Furthermore, the results of this study could also be used as a basis for further research related to the development of religious tourism destinations with 
similar characteristics and cultural backgrounds of the community.

\section{LITERATURE REVIEW}

Currently, it is noted that there is no extensive information on religious tourism due to limited literature. Several studies state that religious tourism begins with the emergence of monotheistic religions (Chami et al., 2020). Religious tourism is a special form of cultural tourism which consists of knowledge about religion and customs as a form of culture. Several studies in the Asian region state that religious tourists are identified as tourists with fanatical religious beliefs. Their belief in the religion they adhere to is an assimilation with the culture of the local community so that it is mixed and is no longer pure like the religious teachings of their place of origin (Larasati and Rahmawati, 2017; Maharani and Setyowardhani, 2018). This is where new activities appear related to cultural beliefs related to religion and give rise to new fanaticism.

The form of fanaticism towards the indigenous culture of an area has led to an exploration of cultural heritage in the past. The results of exploration gradually turned into tourist destinations, usually in the form of temples, inscriptions, and other ancient relics. Cultural heritage is a combination of something tangible and intangible from human activities in the past [5]. This is actively done in many countries to increase tourist visits. Religious tourism itself is a trend in line with the increase in the economy of the world community. Religious tourism is significantly influenced by three components: economy, society, and the environment (Hardini, 2018; Wahyuni, Susilo, \&Muljaningsih, 2018). Preserving cultural heritage requires a lot of money, therefore, without involving the local community, of course, this will be difficult to implement (García et al., 2019). Making cultural heritage as a tourist destination makes economic movement increase, so that awareness of its sustainability can be maintained (Priyanto, 2016; Wahyuni, Susilo and Muljaningsih, 2018). In tourism theory, it is illustrated that sustainable tourism depends on an economic, social, and environmental balance, while a balance can be obtained by preserving cultural heritage (Garcíaet.al., 2016).

\section{RESEARCH METHODS}

Revealing the meaning of satisfaction, which is the spiritual goal of tourists, is the purpose of this study. Since perception needs to be explored, qualitative research methods with phenomenological approach (Corbin \& Strauss, 2008) was conducted. The phenomenological approach describes the meaning of an individual's life experience about a concept or phenomenon (Neuman, 2003). Meanwhile, according to Husserl, phenomenological researchers try to find things that are necessary (essential), invariant structures (essence) or the basic meaning of experience and emphasize the intensity of consciousness where experience consists of things that are visible from the outside and things that are in the awareness of each person based on memory, image and meaning (Neuman, 2003).This research design allows the exploration of informants' experiences about a tourist destination. It also serves as a tool for developing new theories by collecting and analyzing data from multiple perspectives (Corbin, J., \& Strauss, 2008; Neuman, 2003).

\subsection{Informants and Data}

Informants in this study were tourists of religious tourism destinations in the GunungKawi Sacred Cemetery who continued to visit this place during the COVID-19 pandemic. Those who were considered loyal to this tourist destination were selected as informants. Loyalty is assessed based on the frequency of arrival (i.e. more than two visits during the COVID-19 pandemic). This data was obtained from visitors the researchers met during the period May-September 2020. In this study 8 informants were selected. The determination of the number of informants is based on the level of similarity of the answers given, if the answers given are saturated or close to the same as the previous informants' answers, then the number of informants is sufficient and does not need to be added again (Neuman, 2003; Duan and Hoagwood, 2015).

The next step is an open interview, observation and transcripts of the results of the interview (Neuman, 2003). In processing the data, the transcripts were accompanied by information from the observations. Furthermore, coding is carried out in three stages, namely: open coding, axial coding and selective coding. In order for the results to be more convincing, the findings of this study were also discussed with two experts in the field of tourism, who fully understand that this opinion is indeedconsistent with the facts in the field.

\subsection{Research Object}

The object of this research is the GunungKawi Sacred Tomb. The development of Mount Kawi religious tourism begins with the history of the founding of Padepokan R.M Imam Soedjono, a student of EyangJugo (the prince of the Mataram kingdom who fled from the pursuit of the Dutch colonialists). Eyang in this case means elder, someone who is respected and seen as a wise person. Grandma Jugo advised his students to bury his body in PadepokanGunungKawi if he died. From the hermitage, R.M Imam Soedjono spread Islam to local residents who were still Hindu and Buddhist. R.M Imam Soedjono's ability in supranantural terms 
such as: curing illnesses, praying for people to succeed and so on, made the hermitage become famous overseas. Until now, this place is believed to be a place to seek healing or a place for people to pray for wealth/success (Hariyanto, 2018).

\section{RESULT AND DISCUSSIONS}

The results of the interviews indicated that all informants who visited religious tourism destinations were driven by spiritual needs and closeness to the culture they embraced. This is in line with the results of research by Sterchele (2020) and Priyanto (2016). Even though these tourists embrace a certain religion, belief in that culture cannot be separated (Lukiyanto, Widita and Kumalasari, 2018). They come to seek spiritual solutions for their inability to overcome life's problems. Therefore, obstacles such as the COVID-19 pandemic should not be an obstacle to their arrival, instead, it is their hope that after visiting this place they will be free from the impact of COVID-19. Tourists like this are ready to spend money, time, even usually they have planned for years to be able to make this religious visit (Hardini, 2018; Wahyuni et al., 2018).

In the case of religious tourism at the GunungKawi Sacred Tomb, their satisfaction is seen from the success of performing the prayer ritual at that place. After praying they were very sure that what they had asked for would be granted. The first conclusion that can be drawn is: The perception of satisfaction is related to the belief that a prayer that is offered will be answered. This is in line with the results of several studies which state that pilgrims are tourists who believe that prayers made at certain moments or places will receive special blessings from God (Soeryowidagdo, 1989; Hariyanto, 2018).

The characteristics of religious tourists or pilgrims who become informants in this study, based on their educational background, are dominated by highly educated people. This is very different from the general perception of religious tourists. In this study, 6 out of 8 research informants were university graduates, while the rest were high school graduates. This means that these religious tourists are people who understand science and keep up with the news. This made them aware of the importance of the COVID-19 prevention protocol, and comply with it. It is evident that all informants stated that the implementation of the COVID-19 protocol at the GunungKawi Sacred Tombs makes them not worried about coming at any time. When asked if they would come if the COVID-19 protocol was not good, 5 of them said 'no'. The second conclusion that can be drawn from here is: Good implementation of the protocol for preventing the transmission of COVID-19 affects the perception of tourist satisfaction.

\section{CONCLUSIONS}

Two main points that can be drawn as a conclusion are: (1) perception of satisfaction is closely related to the belief in getting answers from prayers that are offered; (2) the implementation of a good protocol for preventing the transmission of COVID-19 predispose the perception of tourist satisfaction. This research is a preliminary study that discusses the development of religious tourism during the COVID-19 pandemic. This early stage research is only limited to finding out how tourists' satisfaction is perceived. Future research may conduct a more indepth investigation of tourist destinations based on the findings of these tourist satisfaction perceptions.

\section{ACKNOWLEDGMENT}

"This work is supported by Research and Technology Transfer Office, Bina Nusantara University as a part of Bina Nusantara University's International Research Grant entitled "Digital Interactive Media Development as Digital Platform for Mapping Tourist Attractions in Greater Malang Based on Kušen's System to Increase The Competitiveness of Tourism In International Scale" with contract number: No.026/VR.RTT/IV/2020 and contract date: 6 April 2020."

\section{REFERENCES}

[1] P. (2018). Barretto, Ziarah in Java Indonesia "s" Conservative Turn' and the IncreasingPopularity of Religious Pilgrimage in Java. Murdoch University. .

[2] D. (2019) Zouni, G., \&Digkas, Marketing suggestions for multi-religious tourism development: The case of Thessaloniki. Journal of Tourism, Heritage \& Services Marketing, $\quad 5(2), \quad 36-42$. https://doi.org/10.5281/zenodo.3601675.

[3] R. (1989). Soeryowidagdo, PesareanGunungKawi: pilgrimage procedures and history of the tomb of EyangPanembahanDjoego, EyangRaden Mas ImanSoedjono at GunungKawi Malang (1st ed.). Malang: GunungKawiPesarean Management Foundation "BaktiLuhur." .

[4] M. (2019). Rasoolimanesh, SM, Md Noor, S., Schuberth, F., \&Jaafar, Investigating the effects of tourist engagement on satisfaction and loyalty.Service Industries Journal, 39(7-8), 559-574. https://doi.org/10.1080/02642069.2019.157 0152. .

[5] S. (2014). Keitumetse, Cultural resources as sustainability enablers: Towards a community-based cultural heritage resources management (COBACHREM) model. Sustainability (Switzerland), 6(1), 70-85. https://doi.org/10.3390/su6010070. . 